Kamila Budrowska

Biatystok

\title{
Cenzurowanie tematyki pogranicza w Polsce Ludowej w latach 1945-1956. Przegląd problematyki badań ${ }^{1}$
}

Słowa kluczowe: cenzura, pogranicze wschodnie, literatura piękna polska, piśmiennictwo naukowe

Tematyką cenzurowania piśmiennictwa w Polsce Ludowej zajmuję się od dawna, niniejsza wypowiedź wynika z wieloletnich badań i kwerend archiwalnych [Budrowska 2009, Budrowska 2013]. Z powodu zainteresowań naukowych $\mathrm{w}$ artykule podejmę zagadnienie oczyszczania z treści niepożądanych literatury pięknej polskiej (zarówno tekstów nowych, jak i wznowień), jako kontekst przywołać także chciałabym kwestię kontrolowania piśmiennictwa naukowego (literaturoznawstwo, historia). Ujęcie takie nie wyczerpuje możliwości badawczych: z pewnością warto byłoby opisać w jaki sposób cenzurowano tematykę pogranicza w literaturze obcej tłumaczonej na polski oraz - co ważne z powodu zasięgu i liczby odbiorców - w prasie. Można również sformułować postulat dalszych badań przekraczających ramy chronologiczne zaproponowane w niniejszym szkicu.

Spuścizna piśmienna po urzędach powołanych w celu kontroli publicznej komunikacji - GUKPPiW (Głównym Urzędzie Kontroli Prasy, Publikacji i Widowisk) i jego oddziałach wojewódzkich - zachowała się w dość dobrym stanie w AAN(Archiwum Akt Nowych)w Warszawie i innych archiwach państwowych na terenie całego kraju. Choć w zespołach uwidaczniaja się ubytki, zwłaszcza bardzo duże braki w materiałach z lat 1945-1948,

\footnotetext{
1 Praca naukowa finansowana w ramach programu Ministra Nauki i Szkolnictwa Wyższego pod nazwą „Narodowy Program Rozwoju Humanistyki” w latach 2012-2017.
} 
licznie zachowane dokumenty (zespół GUKPPiW liczy sobie ok. 5000 teczek, w każdej od kilkudziesięciu do kilkuset kart) mogą stać się podstawą szeroko zakrojonych badań filologicznych, historycznych, socjologicznych, bibliotekoznawczych.

Ze stanu badań [prace historyczne: Drygalski, Kwaśniewski 1992; Nałęcz 1994, Krawczyk 1994; Romek 2000; Pawlicki 2001; Krajewski 2004; Perkowski 2005; Romek 2010; Rokicki 2012; prace filologiczne: Fik 1996; Nycz 1998; Drewnowski 1998; Bates 2000; Hobot 2000; Perkowski 2004; Molisak 2004; Budrowska 2009; Woźniak-Łabieniec 2012], a także kwerendy w materiałach źródłowych wynika, że przez cały okres trwania formacji politycznej zwanej Polską Ludową (od 1952 - Polską Rzeczpospolitą Ludową) niektóre tematy były w literaturze i naukach humanistycznych cenzurowane ostrzej, bardziej wnikliwie. Przedstawię je zbiorczo. I tak, w latach 40. i 50. tropia pracownicy GUKPPiW wszelki nacjonalizm: antysemityzm, elementy antyniemieckie (to po 1949 r. i utworzeniu NRD), a przede wszystkim - antyrosyjskie i antyradzieckie. "Ostrza” ołówków wymierzone są także we wszelkie wstawki religijne, zarówno jeśli chodzi o podjętą tematykę, jak i wymowę ideologiczną utworu; szczególnie dziwacznie brzmią tu negatywne określenia: „ultrakatolicyzm”, „szerzenie katolicyzmu”, „religianctwo", „pozycja metafizyczna”. Wnikliwie czyta się również teksty podejmujące tematykę historyczną, a zwłaszcza, jak pisze Stanisław Siekierski, piśmiennictwo, w którym ujawnia się współczesne życie społeczne [Siekierski 1992, 166]. Tu mieściłyby się ingerencje w treści związane z międzywojniem (zwane „wstecznictwem”), na przykład tematyka związana z Piłsudskim, czy Wilnem. Pojemna ta kategoria obejmuje także utwory podejmujące tematykę II wojny światowej. Z racji rangi, poziomu komplikacji i bardzo częstej obecności zwłaszcza w literaturze pięknej, stanowiące dla cenzorów prawdziwe wyzwanie. Obserwujemy więc kamuflowanie trudnych, niejednoznacznych w ocenie (działalność urzędu miała je ujednoznacznić!) tematów związanych z wojną - Zagłada, wkroczenie Armii Czerwonej na polskie ziemie wschodnie, Katyń, łagry, działalność AK, Powstanie Warszawskie, stosunek żołnierzy radzieckich do polskiej ludności. Jeśli chodzi o problematykę aktualną, najściślej piętnuje się pokazywanie ujemnych stron współczesności, nędzę ludności, społeczną niesprawiedliwość, braki i wypaczenia ustroju, czyli, na przykład, informacje o kolejkach po mięso i przemocy w więzieniach (Kazimierz Brandys, powieść Matka Królów, gdzie wycina się fragment, że w więzieniach swoi bija swoich). Z drugiej strony, piętnuje się brak treści społecznych i politycznych. Niechętnie pisze się tė̇ o emigracji i tych Polakach, którzy wybrali życie na obczyźnie. 
Przedstawione zbiorczo sposoby kontrolowania literatury i naukowego piśmiennictwa humanistycznego zróżnicować można ze względu na czas. Najpoważniejszą zmianą jest inny stosunek cenzorów do problematyki wojennej. W latach 1944-1948 publikuje się wiele dzieł odnoszących do traumatycznych przeżyć związanych z II wojną światową. W okresie stalinowskim wiele z ich okaże się niecenzuralnych. Kolejna odsłona ma miejsce w 1955 r., w okresie „odwilży", gdy niewygodne fakty i ujęcia tematyki okupacyjnej zostają zwolnione $\mathrm{z}$ zakazu. W okresie poprzedzającym wprowadzenie socrealizmu dopuszcza się też istnienie dzieł zawierających wyraźny wydźwięk chrześcijański (na przykład pierwsze wydanie Dymów nad Birkenau Szmaglewskiej). Po 1949 utwory takie albo się wycofuje, albo przekształca. Kolejną z istotnych odmienności wydaje się usilne promowanie w latach 1949-1955 obrazów jasnej rzeczywistości, optymizmu i społecznego zaangażowania. Zmieni się to po ujawnieniu błędów i wypaczeń systemu, w okresie najbardziej liberalnej kontroli możliwe będzie nawet krytykowanie czasów stalinowskich i Urzędu Bezpieczeństwa (Kolumbowie, rocznik dwudziesty Romana Bratnego, czy Matka królów Brandysa). Tematy „rozrachunkowe” będą znów zakazane już przy końcu 1957 r.

Niektóre zagadnienia niepokoją cenzorów przez cały badany okres. Przede wszystkim, absolutnie zabronione jest szkalowanie dobrego imienia ZSRR, w czym mieszczą się - zdaniem urzędników cenzury - i komentarze na temat sytuacji politycznej Polski (polityczna zależność), i wspominanie Kresów Wschodnich, i opis radzieckich więzień i łagrów, czy powstania na Węgrzech. Ścisłej cenzorskiej kontroli i reglamentacji podlega także $\mathrm{w}$ drugiej połowie lat 40. oraz w latach 50. i 60. temat granic (tu obwiązywała dodatkowo cenzura wojskowa) i pograniczy: Warmii i Mazur, Pomorza Zachodniego, Górnego i Dolnego Śląska.

W artykule skupić się chciałabym jedynie na oddaniu sytuacji pogranicza wschodniego, czyli ziem byłego Wielkiego Księstwa Litewskiego (w granicach przedrozbiorowych), w większości utraconych w 1918 i 1944 na rzecz wschodniego hegemona. Opis cenzurowania kwestii innych pograniczy w literaturze, piśmiennictwie naukowym i prasie epoki postawić można jako postulat dalszych badań.

Co spowodowało, że władze PRL uznały wzmianki o tych terenach za niemożliwe do publikacji? Przyczyn można wyliczyć wiele, najważniejsza wydaje się ta, zapisana bezpośrednio w akcie powołującym GUKPPiW do życia.

W Dekrecie z dnia 5 lipca 1946 o utworzeniu Głównego Urzędu Kontroli Prasy, Publikacji i Widowisk czytamy:

„Art. 2. Do zadań Głównego Urzędu należy: 
1) nadzór nad prasą, publikacjami i widowiskami w zakresie przewidzianym w szczególnych przepisach prawnych,

2) kontrola rozpowszechniania wszelkiego rodzaju utworów za pomocą druku, obrazu i żywego słowa, kontrola ta ma celu zapobieżenie:

a) godzeniu w ustrój Państwa Polskiego,

b) ujawnianiu tajemnic państwowych,

c) naruszaniu międzynarodowych stosunków Państwa Polskiego

d) naruszaniu prawa lub dobrych obyczajów,

e) wprowadzaniu w błąd opinii publicznej przez podawanie wiadomości niezgodnych z rzeczywistością (podkr. K. B.)" [Nałęcz 1994, 28].

Zbyt swobodnie podejmowana tematyka wschodniego pogranicza nadwyrężać mogła najważniejszy międzynarodowy sojusz Polski Ludowej - stosunki z ZSRR. Punktów zapalnych - politycznych i społecznych, było po 1944 r. aż nadto: 1. zmiana granicy wschodniej i utrata ogromnych obszarów na rzecz ZSRR, przesuniecie granic kraju na zachód i na północ; 2. przesiedlenia ludności - repatriacje, odbywające się często niezgodnie z prawem międzynarodowym i łamiące prawa człowieka; 3. zantagonizowane po wojnie liczne grupy narodowościowe (mniejszości narodowe) zamieszkujące wschodnie pogranicze: Niemcy, Białorusini, Ukraińcy, Żydzi, Litwini; skomplikowane relacje pomiędzy nimi, nienawiść, lęk, uprzedzenia; 4. kwestia okupacji radzieckiej na tych terenach (okres pomiędzy 17 września 1939 r. a czerwcem 1941 oraz ofensywa roku 1944 i 1945).

„Kształtując nowy porządek i granice po II wojnie światowej, - pisze Zbigniew Kurcz - mocarstwa zdecydowały o znacznych przemieszczeniach ludności. (...) Rządy państw Europy Środkowo-Wschodniej, pomne doświadczeń okresu międzywojennego, zaakceptowały internacjonalistyczną wykładnię kwestii narodowej i nie poświęcały mniejszościom narodowym należytej uwagi. Problemy mniejszości istniejących od dawna, ale też powstałych w wyniku powojennej zmiany granic, zaliczały się do spraw drażliwych, których w imię dalekosiężnych celów wspólnoty państw socjalistycznych, nikt nie chciał podejmować" [Kurcz 1997, 8].

Niemożliwy do realizacji był postulat, by „drażliwa” problematyka wschodniego pogranicza wcale się w publicznym dyskursie, w tym - w literaturze pięknej i piśmiennictwie naukowym, nie pojawiała. Dotyczyła zbyt dużego obszaru powojennej Polski i zbyt wielu jej obywateli. Nie mogło się też udać wyparcie najważniejszej tradycji literackiej i kulturowej - romantyzmu, związanej przecież często z Kresami; wystarczy wymienić Mickiewicza. Zagadnienie podlegało więc bardzo skrupulatnej kontroli i reglamentacji: ujęcia mniej kontrowersyjne mogły się pojawiać po cięciach, ewentualnie 
z odpowiednim komentarzem i „właściwą” interpretacją, bardziej kontrowersyjnych nie publikowano nigdy.

Przyjrzyjmy się teraz kilku charakterystycznym przykładom z kwerendy archiwalnej w zespole GUKPPiW.

Przykładem modyfikowania pamięci zbiorowej tak, by wymazać z niej obraz ziem utraconych na wschodzie są cenzuralne peregrynacje zbioru poetyckiego Kazimiery Iłłakowiczówny. Wiosną 1948 r. do kontroli trafia tomik Wiersze wybrane, zawierający utwory z lat 1912-1945. Wydać zamierza go „Wydawnictwo Zachodnie”. Cenzorska recenzja jest wysoce nieprzychylna, proponuje się usunięcie aż 19 wierszy związanych z Wilnem i tematyką religijną [AAN, GUKPPiW, 169, teczka 1, k. 242]. Na negatywnej ocenie zaważyła i treść liryków, i względy wobec tekstu zewnętrzne (biografia): urodzona na Kresach poetka, była sekretarka Józefa Piłsudskiego, nie mogła liczyć w komunistycznej Polsce na żadne względy. Ostatecznie tomik trafia do druku zubożony jedynie o dwa najbardziej „nieprawomyślne” wiersze: Do Wilna (z obrazem rodzinnego miasta, które teraz opadła sfora psów) oraz Rosjanka (trudny los rosyjskich kobiet).

Szczególna uwaga władz partyjnych, a zatem i wykonujących dyrektywy płynące $\mathrm{z}$ tych gremiów cenzorów, zwrócona na Wilno i Lwów nie dziwi w kontekście historii i znaczenia tych miast - kulturowych centrów pogranicza. W pracy Szkice Wileńskie. Rozprawy i eseje, Tadeusz Bujnicki, Wilnianin z urodzenia, przypomina wielokulturowość miasta, w którym przez wieki funkcjonowały obok siebie kultury i literatury: polska, litewska, białoruska, żydowska, rosyjska, ukraińska, tatarska, karaimska. Miasto było stolicą Litwy, ale także miastem gubernialnym i wojewódzkim, prowincją i metropolią, kresami i centrum. Tu tworzyli Mickiewicz i Miłosz (absolutnie zakazany w okresie PRL), pracował Manfred Kridl i jego szkoła formalna [Bujnicki 2002].

Potwierdzenie niecenzuralnego statusu Wilna odnajdujemy i w materiałach z lat 50 .

W połowie sierpnia 1953 r. do GUKPPiW trafia Wybór wierszy Konstantego Ildefonsa Gałczyńskiego. W opinii pojawiają się charakterystyczne zarzuty i propagandowy język:

Jest to „Wybór wierszy” Gałczyńskiego z całokształtu jego twórczości. Znikomy ich procent zawiera akcenty społeczno-polityczne. (...) Większość wierszy to superformalistyczne, odrealnione, a nierzadko beztreściowe wierszowanie, z którego wprost nie sposób wydobyć myśl autorską. Dość obszernie reprezentowane są wiersze przedwojenne. Część z nich opiewa piękno Wilna i jego okolic. Ze względu na to, że Gałczyńskiego będzie czytała przede wszystkim kołtuneria, nierzadko wzdychająca jeszcze do tamtych 
t e r e nó w (podk. - K. B.) proponuję, aby zostawić jedynie te wiersze z utworów o Wilnie, które posiadają pozytywne akcenty społeczne. (...)" [AAN, GUKPPiW, 386, teczka 31/124, k. 798-799].

Postuluje się liczne poprawki, ostatecznie redakcja musiała skrócić tom (za zgodą autora) o ponad 100 stron! Zmieniono układ całości, wyrzucono wiele wierszy przedwojennych, w tym liczne dotyczące właśnie Wilna i jego okolic. W takiej postaci Wybór wierszy uzyskał akceptację zwierzchnika i mógł ujrzeć światło dzienne w $1954 \mathrm{r}$.

Pogranicze wschodnie to tematyka niebezpieczna także w nauce, przede wszystkim w historii (stosunki polsko-rosyjskie na przestrzeni wieków), ale także w literaturoznawstwie, a nawet - językoznawstwie. Od 1948 r. rozpoczyna się proces etatyzacji nauki, ścisłego planowania, ideologizacji, sygnowanej przygotowaniem I Kongresu Nauki Polskiej, likwidacją Polskiej Akademii Umiejętności i powołaniem Polskiej Akademii Nauk [Hübner 2002, 120 i nast.]. Przełom 1948/1949 r. to także czas wygasania prywatnego, niezależnego od mecenasa państwowego, ruchu wydawniczego, w tym wydawnictw towarzystw naukowych.

Przykładem podjęcia niebezpiecznej, zdaniem cenzorów, tematyki w pracy z dziedziny językoznawstwa jest zgłoszona do wydania w 1951 r. przez Poznańskie Towarzystwo Przyjaciół Nauk książka J. Safarewicza Litewskie nazwy miejscowe na-iszki.

W uzasadnieniu czytamy:

Praca J. Safarewicza jest typowym przykładem pracy „rewindykacyjnej”, omawiającej zagadnienia z terenu pogranicza Litewskiej SRR i Białoruskiej SRR, tak, jak gdyby to dalej były powiaty burżuazyjnej Polski. (..) Należy ostatecznie przekonać naszych uczonych, żeby zajęli się sprawami polskimi a nie ziemiami w ich zrozumieniu „utraconymi”. (...). [AAN, GUKPPiW, 402, teczka 32/46, k. 8].

Opracowanie na temat pogranicza polsko-litewskiego nie mogło zostać wydane w apogeum stalinizmu, choć poprzedzała je publikacja o zbliżonej problematyce z 1947 [Safarewicz 1947]. Artykuł zostaje ,zwolniony” z zapisu w czasie odwilży w 1956 r., gdy ogłasza autor w czasopiśmie naukowym tekst pod tym samym tytułem, jak w zatrzymanym przez GUKPPiW pięć lat wcześniej [Safarewicz 1956].

Prace naukowe podlegały ścisłej kontroli nie tylko ze względu na treść, ale i osobę autora. Podobnie jak w przypadku literatury pięknej (casus Iłłakowiczówny). Ukrywa się biografię autorów, jeśli pochodzili z Kresów Wschodnich, a zwłaszcza fakt pracy na Uniwersytecie Stefana Batorego 
w Wilnie i Uniwersytecie Jana Kazimierza we Lwowie. Warto jako przykład przytoczyć opinię z $1950 \mathrm{r}$., gdy cenzor z oburzeniem pisze o zgłoszonym do druku roczniku Towarzystwa Naukowego Warszawskiego:

Proponowany do druku rocznik jest jednym z większych skandali politycznych, jakie zdarzyło mi się dostać do oceny. Bowiem w spisie członków zwyczajnych, nadzwyczajnych i korespondencyjnych znajduje się aż dwunastu, przy których jako adresy podano bądź Londyn, bądź też dokładne adresy angielskie i amerykańskie tych emigrantów. (...)

Ponadto przy kilku profesorach podane jako uczelnia i miejsce zamieszkania: Lwów, np. Dąbkowski Przemysław (adres...), Makarewicz Juliusz (adres), a chodzi tu o profesorów, którzy na pewno we Lwowie obecnie nie są i nie wykładają.

Trudno tego rodzaju fakty traktować jako niedopatrzenia. Jest to świadome szkodnictwo, otwarta wroga robota polityczna. Należy nie tylko nie dopuścić do druku rocznika, ale zainteresować tą sprawą władze bezpieczeństwa i Ministerstwo Nauki i Szkół Wyższych. Czas najwyższy, aby towarzystwo utrzymujące się z budżetu państwowego zdecydowało się czy idzie z Polską Ludową, czy przeciw. (...)

Całkowicie nie nadaje się do druku. [AAN, GUKPPiW, 176, k. 340-341]

Rocznik ogłoszono drukiem dopiero po gruntownych zmianach, co poświadczają inne zachowane $\mathrm{w}$ zespole recenzje. [AAN, GUKPPiW, 176, k. 360-361]

W związku ze skomplikowaną historią ziem pogranicznych wprowadza władza ludowa nową narrację historyczną dotyczącą współczesności, a zwłaszcza okresu II wojny światowej. Jako egzemplifikacje warto przytoczyć edytorskie dzieje utworu zatrzymanego w całości, jednego ze słynnych „półkowników”, objętego zapisem w latach stalinowskich [Budrowska 2009, 53; Bikont, Szczęsna 2006, 239].

Polska jesień Jana Józefa Szczepańskiego ukończoną w 1949 r. do urzędu cenzury z zamiarem wydania zgłosiło krakowskie „Wydawnictwo Literackie” w 1955 r. Zachowana recenzja nosi już typowe znamiona odwilży, a mimo to, razi propagandowym ujęciem kwestii radzieckiej aneksji wschodnich ziem II Rzeczypospolitej:

„(...) Należy podkreślić, że w pewnym przypadku popełnia autor poważny błąd historyczny. Wkroczenie wojsk radzieckich na tereny zamieszkałe przez ludność ukraińską i białoruską miało miejsce wg pozycji w okresie, kiedy oddziały armii polskiej walczyły jeszcze z najeźdźcą, a rząd polski nie uciekł jeszcze na terytorium rumuńskie, tzn. przed 17 września. (...) Jest to poważna nieścisłość historyczna i może być wykorzystana jako argument przeciwko słusznemu posunięciu rządu radzieckiego, zwłaszcza, że podobne próby były już czynione w tym kierunku. Usiłowano twierdzić, że był to 
„cios w plecy” zadany przez ZSRR itp. Fakty podane przez autora moga to zasugerować. (...) Jeżeli chodzi o walory artystyczne pozycji stwierdzić należy, że stoi ona na poziomie raczej przeciętnym. Język prosty, zawierający wiele naturalizmu. Akcja niezbyt zróżnicowana, ale zawierająca sporo humorystycznych momentów. Ze względu na jej demaskatorski i realistyczny charakter pozycją jest ciekawą i interesującą i może zostać wydaną." (podkr. - K B.) [AAN, GUKPPiW, 395, teczka 32/12, k. 27-28]

Pomimo nieprzychylnych opinii, powieść została wydana bez zmian w dużym nakładzie 10000 egzemplarzy.

Wraz z przesunięciem granic na zachód, stopniowemu zacieraniu ulega sama tematyka kresowa w literaturze pięknej: by nie było „nostalgii” i ewentualnego „myślenia rewindykacyjnego”. Przywoływanym przykładem takich działań cenzury jest potraktowanie wierszy Gałczyńskiego. Podobny wydaje się przypadek Polskiej jesieni Szczepańskiego: nawet samo pisanie o działaniach wojennych na tych terenach, wydarzeniach znajdujących się przecież w pamięci bezpośredniej wielu Polaków, okazuje się głęboko niecenzuralne. Tylko w okresie rozliczania się z „błędami i wypaczeniami” systemu dzieła tej miary mogły ujrzeć światło dzienne bez przeszkód. Na pełny powrót tematyki kresowej w literaturze i oficjalnym dyskursie czekać trzeba będzie aż do roku 1989.

Chciałabym na koniec wspomnieć o jeszcze jednym ciekawym aspekcie cenzurowania kwestii wschodniego pogranicza. Otóż reglamentacji podlegało samo słowo „Kresy”, domyślnie: „Kresy Wschodnie”. Nie wchodząc w istotę zagadnienia o tożsamości, bądź rozłączności obu pojęć, na użytek niniejszych rozważań przyjmę optykę wybitnego historyka - Jana Kieniewicza. „Chcę zatem wskazać - pisze Kieniewicz w rozprawie Kresy jako przestrzeń europejska, - że Kresy można rozpatrywać jako typ Pogranicza cywilizacji europejskiej, jako część przestrzeni europejskiej. Jest to zasadne zarówno w okresie ekspansji, jak i w czasie ustępowania" [Kieniewicz 2006, 23]. Władze PRL nie odróżniały odcieni znaczeniowych terminów, traktując „Kresy" jako synonim wschodniego pogranicza i ściśle nadzorując jego niepojawianie się w obiegu oficjalnym. Wydaje się, że spowodowane to było wzmiankowaną wyżej potrzebą rugowania tematyki kresowej oraz niechęcią do dorobku kulturowego II Rzeczypospolitej, dla której legenda tych ziem okazała się jedną z centralnych. "Mit kresowy" stworzony w wieku XVI, a rozrastający się zwłaszcza w okresie zaborów, budowały treści dla nowej władzy niebezpieczne, wręcz wywrotowe: mit narodzin państwa polskiego jako Rzeczypospolitej Obojga Narodów, wspólny dla wszystkich Słowian mit przodków - Sarmatów, mit szlachetnej i silnej Sarmacji - fundamentalna ideologia monarchii Jagiellońskiej [Hadaczek 2003, 80-99]. 


\section{Źródła}

\section{Rozwiązanie skrótów}

AAN - Archiwum Akt Nowych

GUKPPiW - Główny Urząd Kontroli Prasy, Publikacji i Widowisk

\section{Źródła przywołane w artykule}

AAN, GUKPPiW, 169, teczka 1

AAN, GUKPPIW, 386, teczka 31/124

AAN, GUKPPiW, 402, teczka 32/46

AAN, GUKPPiW, 176

AAN, GUKPPiW, 395, teczka 32/12

\section{Literatura}

Bates J. M., 2000, Cenzura w epoce stalinowskiej, „Teksty Drugie” nr 1/2, s. 95-120.

Bikont A., Szczęsna J., 2006, Lawina i kamienie. Pisarze wobec komunizmu, Warszawa.

Bujnicki T., 2002, Szkice Wileńskie. Studia i rozprawy, Kraków.

Budrowska K., 2009, Literatura i pisarze wobec cenzury PRL. 1948-1958, Białystok.

Budrowska K., 2013, Zatrzymane przez cenzure. Inedita z połowy wieku XX, Warszawa.

Cenzura w PRL. Relacje historyków, 2000, opr. wst. Z. Romek, Warszawa.

Drygalski J., Kwaśniewski J., 1992, (Nie)realny socjalizm, Warszawa.

Dokumenty do dziejów PRL. Gtówny Urząd Kontroli Prasy 1945-1949, 1994, z. 6, opr. D. Nałęcz, Warszawa.

Drewnowski T., 1998, Cenzura w PRL a współczesne edytorstwo, [w:] Autor, tekst, cenzura. Prace na Kongres Slawistów w Krakowie, red. J. Pelc, M. Prejs, Warszawa, s. 13-23.

Fik M., 1996, Cenzor jako współautor, [w:] Literatura i władza, red., sł. wstępne E. Sarnowska-Temeriusz, Warszawa, s. 131-147.

Hadaczek B., 2003, U narodzin mitów kresowych, [w:] Poszukiwanie realności. Literatura - dokument - kresy. Prace ofiarowane Tadeuszowi Bujnickiemu, red. S. Gawliński, W. Ligęza, Kraków, s. 80-99.

Hobot J, 2000, Gra z cenzurą w poezji Nowej Fali (1968-1976), Kraków.

Hübner P., 1992, Polityka naukowa w latach 1944-1953. Geneza systemu, t. I. Wrocław.

Kieniewicz J., 2006, Kresy jako przestrzeń europejska, [w:] Dziedzictwo kresów nasze wspólne dziedzictwo?, red. J. Purchla, Kraków, s. 234-256.

Krajewski A., 2004, Między wspótpraca a oporem. Twórcy kultury wobec systemu politycznego PRL (1975-1980), Warszawa. 
Krawczyk A., 1994, Próba indoktrynacji. Działalność MIiP (1944-1947), Warszawa.

Kurcz Z., 1997, Wstęp, [w:] Mniejszości narodowe w Polsce, red. Z. Kurcz, Wrocław, s. $6-11$.

Molisak A., 2004, Judaizm jako los: rzecz o Bogdanie Wojdowskim, Warszawa.

Nycz R., 1998, Literatura polska w cieniu cenzury (Wykład), „Teksty Drugie” nr 3, s. $5-25$.

Pawlicki A., 2001, Kompletna szarość. Cenzura w latach 1965-1972. Instytucja i ludzie, Warszawa.

Perkowski P., 2004, Cenzura jako źródto cierpień? Powieści Tadeusza Konwickiego $w$ obliczu kontroli stowa. Niepublikowana praca magisterska napisana pod kierunkiem prof. dr hab. M. Czermińskiej, Gdańsk.

Perkowski P., 2005, Działalność Głównego Urzędu Kontroli Prasy, Publikacji i Widowisk $w$ latach siedemdziesiatych. Niepublikowana rozprawa doktorska napisana pod kierunkiem dr hab. Barbary Okoniewskiej, prof. UG, Gdańsk.

Rokicki K., 2012, Relacje między literatami a władzami PRL w latach 1956-1970, Warszawa.

Romek Z., 2010, Cenzura a nauka historyczna w Polsce. 1944-1970, Warszawa.

Safarewicz J., 1947, Rozmieszczenie nazw na - „iszki” na pograniczu słowiańsko-litewskim, [w:] Sprawozdania PAU, t. XLVIII, Kraków, s. 36-74.

Safarewicz J., 1956, Litewskie nazwy miejscowe na -iszki, „Onomastica”, t. 2, s. $15-63$.

Siekierski S., 1992, Ksiązka literacka. Potrzeby spoleczne a ich realizacja w latach 1944-1986, Warszawa.

Woźniak-Łabieniec M., 2012, Obecny nieobecny. Krajowa recepcja Czesława Miłosza w krytyce literackiej lat pięćdziesiątych w świetle dokumentów cenzury, Łódź.

CENSORSHIP OF THE BORDER-LINE PROBLEMS IN THE PEOPLES

REPUBLIC OF POLAND IN THE LITERATURE OF THE 1945-1956 YEARS.

A REVIEW OF THE PROBLEMS

S U M M A R Y

The article is dedicated to one of the categories of the censors' practices in the Peoples Republic of Poland in the 40s and 50s literature of the 20th century: censored of the border-line-subject. These problem was one of the most controlled and purished in Poland of political reason by the Main Office of Control of Press, Publication and Shows (GUKPPiW), especially - the east border - line problem. Of the examples of literature texts (Konstanty Ildefons Gałczyński, Kazimiera Iłłakowiczówna, Jan Józef Szczepański) and the science - texts, the author described complicated political and cultural situation in socialist countries in the $40 \mathrm{~s}$ and $50 \mathrm{~s}$ of the XX century.

Kamila Budrowska e-mail: kamilabudrowska@interia.pl 